\title{
PLANEJANDO UMA PLATAFORMA TECNOLÓGICA INTEGRADA PARA A GESTÃO E REDUÇÃO DE DESASTRES NA REGIÃO DA AMÉRICA LATINA E CARIBE-ALC NO SÉCULO XXI.
}

\author{
HACIA UN MARCO TECNOLÓGICO INTEGRADO DE GESTIÓN Y REDUCCIÓN \\ DE DESASTRES PARA LA REGIÓN DE AMÉRICA LATINA Y CARIBE EN EL \\ SIGLO XXI.
}

\section{TOWARD AN XXI CENTURY INTEGRATED TECHNOLOGICAL FRAMEWORK TO SUPPORT DISASTER MANAGEMENT AND REDUCTION IN THE LATIN AMERICA AND CARIBEAN LAC REGION.}

Ronaldo Lyrio BORGO ${ }^{1}$

\begin{abstract}
RESUMO: Há grandes motivações globais para empreender cooperação internacional em Ciências e Tecnologias, com expectativas de planejamento a médio prazo (2022), para apoiar estratégias de reforço na construção de capacitações nacionais e regionais para a redução e gestão do risco de desastres. A Comunidade de Estados da América Latina e do Caribe (CELAC) e a União de Nações Sul-Americanas (UNASUL) avançam com novos planos de cooperação a partir de 2015, para reforçar as capacitações em gestão de desastres (DRM) existentes, e promover a redução de riscos de desastres (DRR) na região.
\end{abstract}

Palavras-chave: Ciência e Tecnologia, Cooperação Internacional, Programas regionais para a redução e gestão do risco de desastres.

RESUMEN: Hay grandes motivaciones globales para realizar la cooperación internacional en ciencia y tecnología, con las expectativas de planificación a mediano plazo (2022), para apoyar las estrategias de fortalecimiento en la construcción de capacidades nacionales y regionales para la reducción de desastres y gestión de riesgos. La Comunidad de Estados Latinoamericanos y Caribeños (CELAC) y la Unión de las Naciones Suramericanas (UNASUR) presentaron nuevos planes de cooperación a partir de 2015 para fortalecer las capacidades en gestión de desastres (DRM) existentes y promover reducción del riesgo de desastres (RRD) en la región.

Palabras clave: Ciencia y Tecnología, la cooperación internacional, los marcos regionales para la reducción del riesgo de desastres y la gestión

\footnotetext{
${ }^{1}$ Msc Telecommunication Electrical Engineer. S\&T Senior Analist at CNPq.
} 
ABSTRACT: There are great global motivations to hold Science and Technology International cooperation planning expectations in the medium term 2022, to support strategies to reinforce national and regional capacity building of collaborative frameworks for disaster risk reduction and management. The Latin American and Caribbean States Community (CELAC) and the Union of South American Nations (UNASUR) they push ahead new cooperation plans from 2015 to reinforce their existing DRM and promote the DRR in the.

Key Words: Science and Technology, International cooperation, regional frameworks for disaster risk reduction and management.

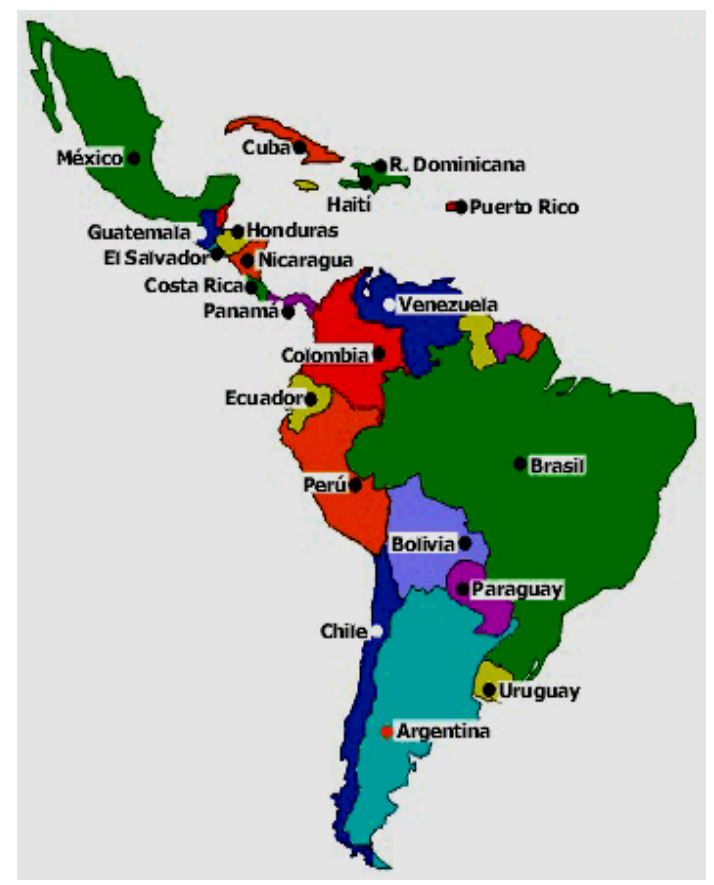

\section{Introduction About the Regional Organizations}

Many efforts to converge disaster risk reduction (DRR) and disaster management (DM) actions in LAC region become in this century as aggregator of experience in this area of knowledge that has great expression consolidated and experienced from the last century in Latin America and the Caribbean. The LAC region holds a historical avant-garde in founding different organizations dealing with disaster risk management (DRM or DM), marked by the sub-regional organizations: CARICOM, SICA and the ANDEAN COMMUNITY, and the specific entities to deal with DRM issues: the Agency of the Caribbean Disaster Emergency Management (CDEMA), the Coordination Center for the Prevention of Natural Disasters in 
Central America (CEPREDENAC) and the Andean Committee for Disaster Prevention and Assistance (CAPRADE). Central America and the Caribbean are among the first regions with regional organizations work on DRM. CEPREDENAC was founded in 1987 and the predecessor of CDEMA was founded in 1991 - at least five to ten years before most other regions have begun to seriously look DRM on a regional level. [2] The forward list of regional organizations and their treated-based frameworks shows the chronological references. $^{2}$

\begin{tabular}{|c|c|c|}
\hline Regional Organization" & DRR Framework & DM Framework \\
\hline \multicolumn{3}{|l|}{ AFRICA } \\
\hline $\mathrm{AU}$ & 2004 & in development \\
\hline ECOWAS & 2007 & 2012 (humanitarian policy) \\
\hline SADC & $2005-6$ & 2001 \\
\hline \multicolumn{3}{|l|}{ AMERICAS } \\
\hline OAS & & 2003 \\
\hline SICA/CEPREDENAC & & 1999 \\
\hline CARICOM/CDEMA & & 2001 \\
\hline CAN/CAPRADE & & 2004 \\
\hline \multicolumn{3}{|l|}{ ASIA } \\
\hline LAS & 2010 & 1990 \\
\hline SAARC & & 2007 \\
\hline ASEAN & & 2005 \\
\hline \multicolumn{3}{|l|}{ EUROPE } \\
\hline EU & 2009 & 2001 \\
\hline Council of Europe & & 1887 \\
\hline \multicolumn{3}{|l|}{ PACIFIC } \\
\hline Regional Pacific Framework & & 2005 \\
\hline
\end{tabular}

In all regions under consideration, there are only three treaties legally-binding agreements that specifically deal with disaster management as their primary focus: ASEAN's Agreement on Disaster Management and Emergency Response, SAARC's Agreement on Rapid Response to Regional Disasters and CARICOM's Caribbean Disaster Emergency Response Agency (CDERA) Agreement (the successor, CDEMA).

\footnotetext{
${ }^{2}$ Elizabeth Ferris and Daniel Petz. In the Neighborhood: The Growing Role of Region al Organizations in Disaster Risk Management. The Brookings Institution - London School of Economics Project on Internal Displacement. February 2013
} 
These treaties SAARC/ASEAN from Asia and CDERA/CARICOM from Caribe, address substantively similar issues as the more widely adopted strategic plans and programs, such as preparedness, emergency response, and technical cooperation. They are the tips of regional launches whose efforts in international cooperation broke scarcity of resources and barriers of regional support funds trying to arrange the risk reduction ahead of disaster management.

Although it is the largest sub-region of Latin America, the South America has the smaller portion of the world regional organizations so far, and start from 2015 the policy blocks UNASUR and CELAC new agreements pulling the Brazil and South America region DRR and DRM delayed wagons. Up to now in the context of organizations and regional mechanisms for disaster management in LAC, there is evidence of one sub-regional initiative in the form of Framework based on Treaty in South America by 2014: The Andean Strategy for Disaster Prevention and Response (EAPAD), has been adopted under the auspices of the Andean Community and its Cartagena Agreement, that converged issues on DRR and DRM. [2]

In addition to regional organizations some funds cover investments in disaster reduction with emphasis on the World Bank and the Global Facility for Disaster Reduction and Recovery (GFDRR). ${ }^{3}$ The tables below show the priorities of GFDRR between 20152017.

\begin{tabular}{|c|c|c|c|}
\hline \multicolumn{2}{|c|}{ Indicator / Requirement (FY15-17) } & Base Case & Investment Case \\
\hline Resources & Projected Work Plan allocations & $\$ 25$ million & $\$ 170$ million \\
\hline Prioritization & Priority Countries & 20 countries & $\begin{array}{l}\text { Up to an additional } \\
34 \text { countries }\end{array}$ \\
\hline \multirow{4}{*}{ Results } & $\begin{array}{l}\text { Enabling large-scale programs in } \\
\text { DRM }\end{array}$ & $\begin{array}{l}15 \text { large-scale programs } \\
\text { enabled / supported }\end{array}$ & $\begin{array}{l}55 \text { large-scale programs } \\
\text { enabled / supported }\end{array}$ \\
\hline & $\begin{array}{l}\text { Capacity Building: \# of capacity } \\
\text { building measures }\end{array}$ & 49 & 460 \\
\hline & $\begin{array}{l}\text { Analytical Products: \# of analytical } \\
\text { products }\end{array}$ & 33 & 270 \\
\hline & $\begin{array}{l}\text { Technical Assistance: \# of } \\
\text { technical and implementation } \\
\text { assistance activities }\end{array}$ & 56 & 315 \\
\hline
\end{tabular}

\footnotetext{
${ }^{3}$ Managing Disaster Risks for a Resilient Future.A Work Plan for the Global Facility for Disaster Reduction and Recovery 2015 - 2017. GFDRR
} 


\begin{tabular}{|c|c|c|c|}
\hline & \multirow{2}{*}{$\begin{array}{l}\text { Base Case } \\
\text { Current Priority }\end{array}$} & \multicolumn{2}{|c|}{ Investment Case } \\
\hline & & $\begin{array}{l}\text { Previously Benefiting from } \\
\text { Donor Earmark }\end{array}$ & Additional Proposed \\
\hline AFR-Africa & $\begin{array}{l}\text { Burkina Faso, Ethiopia, Ghana, } \\
\text { Madagascar, Malawi, Mali, } \\
\text { Mozambique, Senegal, Togo }\end{array}$ & & $\begin{array}{l}\text { Burundi, Cameroon, } \\
\text { Chad, Mauritania, Nigeria, } \\
\text { Tanzania }\end{array}$ \\
\hline $\begin{array}{l}\text { EAP-East Asia } \\
\text { and Pacific }\end{array}$ & $\begin{array}{l}\text { Indonesia, Marshall Islands, } \\
\text { Papua New Guinea, Solomon } \\
\text { Islands, Vietnam }\end{array}$ & $\begin{array}{l}\text { Lao PDR, Philippines, } \\
\text { Vanuatu }\end{array}$ & $\begin{array}{l}\text { Cambodia, Fiji, Kiribati, } \\
\text { Micronesia, Samoa, } \\
\text { Timor-Leste, Tonga }\end{array}$ \\
\hline $\begin{array}{l}\text { ECA-Europe and } \\
\text { Central Asia }\end{array}$ & Kyrgyz Republic & & Georgia, Uzbekistan \\
\hline $\begin{array}{l}\text { LCR-Latin America } \\
\text { and Caribbean }\end{array}$ & Haiti, Panama & $\begin{array}{l}\text { Colombia, Costa Rica, } \\
\text { Ecuador, Guatemala }\end{array}$ & $\begin{array}{c}\text { Bolivia, El Salvador, } \\
\text { Honduras, Nicaragua, Peru }\end{array}$ \\
\hline $\begin{array}{l}\text { MNA-Middle East } \\
\text { and North Africa }\end{array}$ & Djibouti, Yemen Republic & & Algeria, Egypt \\
\hline SAR-South Asia & Nepal & $\begin{array}{l}\text { Bangladesh, Pakistan, } \\
\text { Sri Lanka }\end{array}$ & Afghanistan, Bhutan \\
\hline
\end{tabular}

\section{The LAC regional integration new political actions for disaster management and reduction in the XXI century.}

An Latin American integrated regional initiative for disaster reduction and management strategy in the twenty-first century it started in 2015 promoted by a intergovernment policy blocks major force driving work plans for the short (2015) and medium (2022) terms, in the context of regional integration of the Latin American and Caribbean States Community (CELAC) and the Union of South American Nations (UNASUR) [1].

The CELAC grand challenges forsee an integrated approach to improve a disaster risk management regional program in accordance with the Community of Latin American and Caribbean States Plan of Action, CELAC- $2015^{4}$ for Regional and International Cooperation in Latin America and the Caribbean transcript from the official text: "HUMANITARIAN ASSISTANCE IN CASES OF INTERNATIONAL DISASTER:

1- To hold the First Meeting of the Working Group of Senior Officials on Comprehensive Disaster Risk Management during the First Half of 2015, regardless of the VII Meeting of MIAH to develop a regional action plan on the matter, including proposals for disaster risk reduction and humanitarian assistance for the development of a Regional Strategic Agenda for Comprehensive disaster Risk Management. The Plan and Agenda must consider and act

\footnotetext{
${ }^{4}$ www.rree.go.cr/celac/cumbre/
} 
in a complementary and coordinated with the efforts and regional and subregional cooperation and coordination on these issues.

2- To reiterate the request to the FAO and the World Food Programme (WFP) to provide technical support in order to design and implement regional initiatives aimed at the prevention, reduction and disaster risk management. ";

3. Deepen the collaboration and coordination with the process of International Humanitarian Assistance Mechanisms (MIAH).

Indeed, the CELAC's plan leaves the UNISDR Las Americas rhetoric policy and invests in the coalition forces and union of treaties, mechanisms and cooperation programs already under way since the last century, around the Regional Strategic Agenda for Comprehensive disaster Risk Management, the FAO and the world Food Programme (WFP) and the International Humanitarian Assistance Mechanisms (MIAH), seeking diverse partnerships in the setting of new world economic order blocks such as the BRIC's besides the European Union, and alternatives to the FMI and the World Bank.[1]

Moreover the regional initiative requires the efforts of intergovernmental policy and technological innovation, which is already underway within the UNASUR as a new chapter of IIRSA - Integration of Regional Infrastructure in South America. The Guidelines UNASUR / IIRSA-COSIPLAN ${ }^{5}$ Work Plan 2015, Action 6.1.5 - Prevention and Management of Risks and Disasters in infrastructure, which began in 2015, should extended the "Implementation Methodology DRGs Integration Infrastructure Projects Exposed to Seismic Hazards in the Chilean and Peruvian Territory" to all of South America. To emphasize the evidence of these statements quoted text:

"... The Plan of Action COSIPLAN / IIRSA2 2012-2022 (PAE 2012-2022), Chapter 6.1.5: Disaster management in infrastructure, provides a specific need for progress on the issue of risk management disaster (GRD), to which member countries have clear procedures to prevent and reduce the effects of catastrophic events (earthquakes, floods, landslides and tsunamis) affecting the South American infrastructure integration and establish recovery plans connectivity and public infrastructure designed with methodologies for disaster risk management. "

${ }^{5} \mathrm{http}: / /$ www.iirsa.org/ 
About the LAC region integrated technical-scientific framework proposal based on the MainStream of Space based technologies applied to disaster management and reduction

Thinking on the near future and considering the crescent disaster economic losses and life losses, the LAC regional framework for disaster management and reduction in the medium and long term could be based on the CELAC and UNASUR Information and Communication Society and Space based infrastructure integration plans to promote the construction of their own main regional operational technological system in Latin America and the Caribbean, taking into account that currently some private consortia of satellite operators provide alternative systems like a comodity. It's a large branch of technological infrastructure network and computing engineering shall be planned and projected at regional and local level. This regional framework in LAC can and should be well financed by banks that support these new political blocs ( UNASUR , CELAC) beyond the banks that support the economic blocs that cooperate with them as the BRICS and the EU. [2,5]

The Committee on the Peaceful Uses of Outer Space COPUOS Report on the United Nations International Conference on Space-based Technologies for Disaster Management: Multi-hazard Disaster Risk Assessment (Beijing, 15-17 September 2014) takes firm stand and declares:

"Rapid development is making human settlements in developing countries prone to disasters. Extreme weather conditions related to climate change are aggravating disaster risks. Although good progress has been made in enhancing early warning and emergency response capacity in developing countries, not much has been done to identify, assess and monitor disaster risks, in spite of what has been envisaged in the Hyogo Framework for Action. To mitigate the global challenges referred in the proposed post-2015 development agenda, building-disaster resilience is a key factor in all developmental processes. Mitigating one type of risk may sometimes increase the risk of another disaster. Therefore, multi-hazard disaster risk assessment is essential to providing balanced disaster management efforts."[3]

Despite technological advances in Earth observation and ground-based systems for disaster prediction and monitoring, several countries still face challenges in assessing and reducing disaster risk. Those challenges may be addressed by setting up a mechanism for identifying, assessing, monitoring and responding to disaster risks. With advances in Earth observation technologies and increasing access to space-based information, several 
opportunities are available for disaster managers to use space technologies for effective disaster management.[3]

Space-based technologies, especially Earth observation, provide valuable information on both sudden-onset and slow-onset hazards, including information on land cover and exposure of assets for risk assessment and information that can be used to improve warning service and response capability. Recognizing the usefulness of space-based information, the Committee on the Peaceful Uses of Outer Space has stressed that "loss of life ... could be diminished if better information were available through improved risk assessment, early warning and monitoring of disasters.[3]About such subjects of research in the light of a mainstream "Bringing the Benefits of Space to Humanit", the United Nations Office for Outer Space Affairs (UNOOSA) declares the following:

"Given the inherent global nature and reach of space activities, space science and technology play an ideal role in providing solutions to global problems. In that context, the work of UNOOSA includes implementing the global platform for disaster management (UN-SPIDER), promoting the global search and rescue system (COSPASSARSAT), addressing the issues of interoperability and compatibility of global navigation satellite systems through the International Committee on Global Navigation Satellite Systems (ICG), and overseeing the global array of instruments for studying space weather and the profound impact of the Sun on the Earth."

The synergistic cooperation with international initiatives for public protection and disaster mitigation, which are in the scope of the United Nations International Strategy for Disaster Reduction Framework (UNISDR Americas) supported on the Space based Platform for disasters Management Services (UNSPIDER) focal points, and with some extra-regional frameworks like the ASEAN (in Asia and the Pacific) framework suported by space technologies "ASIA SENTINEL", is a great start to safeguard the LAC region of disasters, save lives and save infrastructure and housing, while follows the planning and implementation of the propositional framework in the medium term 2015-2020.[4,5]

\section{References}

[1]CELAC, UNASUL/IIRSA/COSIPLAN 
CELAC Action Plan 2015- INTERNATIONAL HUMANITARIAN ASSISTANCE IN CASES OF DISASTER. III Cumbre CELAC Costa Rica 2015.

Gestión de riesgo de desastres en la infraestructura de integración de COSIPLAN/IIRSA.Manual de Usuario. Orientaciones para emprender análisis de riesgo. Versión para ser usada en pilotaje 2015. UNASUL/IIRSA/COSIPLAN, Montevideo, novembro 2014.

PLAN DE ACCIÓN ESTRATÉGICO 2012-2022. CONSEJO SURAMERICANO DE INFRAESTRUCTURA Y PLANEAMIENTO(COSIPLAN)

\section{[2] International Cooperation branch}

BORGO, Ronaldo Lyrio \& SILVA, Darly Henriques da. Disaster Risk Reduction. UNISDR 2014 Regional Conferences and the S\&T International cooperantion perspectives. Issued as contribution to "Pré-zero draft of the Post-2015 framework for disaster risk reduction" UNISDR document assesment,to the UNISDR Brazil Central Office and to theThe Global Network of Science Academies IAP director. Published at the Revista Terceiro Incluído ISSN 2237-079X NUPEAT-IESA-UFG, 2014, DOI: 10.5216/teri.v4ij.33945(83-96).

FAGEN, Patricia Weiss. "Natural Disasters in Latin America and the Caribbean: National, Regional and International interactions" HPG Working Paper, October 2008, FERRIS, Elizabeth \& PETZ, Daniel. In the Neighborhood: The Growing Role of Region al Organizations in Disaster Risk Management. The Brookings Institution - London School of Economics Project on Internal Displacement. February 2013

FERRIS, Elizabeth. Better Together: Regional Capacity Building for National Disaster Risk Management.Desk Review ,August 6, 2014.

Managing Disaster Risks for a Resilient Future.A Work Plan for the Global Facility for Disaster Reduction and Recovery 2015 - 2017. GFDRR

\section{[3]UNOOSA/COPUOS- APSCO}

Role of Asia Pacific Space Cooperation Organization in Space-based Disaster Risk Management. Asia-Pacific Space Cooperation Organization APSCO. United Nations International Conference on Space based Technologies for Disaster Management

“Multi hazard Disaster Risk Assessment” 15-17 Sept, 2014, Beijing, China

Report on the United Nations International Conference on Space-based Technologies for Disaster Management: Multi-hazard Disaster Risk Assessment.(Beijing, 15-17 September 2014) Committee on the Peaceful Uses of Outer Space COPUOS- A/AC.105/1076.

Report on the United Nations/Germany Expert Meeting on the Use of Space-based Information for Flood and Drought Risk Reduction. (Bonn, Germany, 5-6 June 2014) Committee on the Peaceful Uses of Outer Space COPUOS- A/AC.105/1074

Report on the United Nations International Conference on Space-based Technologies for Disaster Management: Disaster Risk Identification, Assessment and Monitoring (Beijing, 23- 
25 October 2013) Committee on the Peaceful Uses of Outer Space COPUOS A/AC.105/1061.

United Nations International Conference on Space based Technologies for Disaster Risk Management "Best Practices for Risk Reduction and Rapid Response Mapping" Organised by the United Nations Office for Outer Space Affairs (UNOOSA/UNSPIDER) and Ministry of Civil Affairs of the People's Republic of China 22 - 25 November 2011 Beijing, CHINA

Marboe Irmgard, Balogh Werner. International Organizations and Agreements. General Legal Framework of the Use of Outer Space Technologies. 11 November 2009. University of Vienna UNIVIE \& United Nations Office for Outer Space Affairs UNOOSA.

\section{[4]WMO UNOOSA UNSPIDER EUMETSAT}

EUMETSAT's new satellite programs: Services continuity, improvements and innovations. EUM/CS/VWG/14/744207 AMS Annual Meeting Atlanta 2014, $10^{\text {th }}$ Annual Symposium on New Generation of Operational Environmental Satellite Systems.

Space and Climate Change - Use of space-based technologies in the United Nations System. World Meteorological Organization WMO, 2011.No. 1081.

VILLAGRAN. J. \& STUMPF, P..United Nations Platform for Space-based information for Disaster Management and Emergency Response (UN-SPIDER) Knowledge Portal: Gateway to Space-Based Information for Disaster Risk Management and Emergency Response. UNOOSA, Scientific and Technical Subcommittee: 2014 Fifty-first session. 1021 February 2014.Technical Presentations.

KAKU, Kazuya, HELD, Alexander. Sentinel Asia: A space-based disaster management support system in the Asia-Pacific region. International Journal of Disaster Risk Reduction. 2013 The Authors. Published by Elsevier Ltd. All rights reserved.

\section{[5] Article , Mograph, Dissertation}

- Borgo, R. L. About the extreme climate changes adaptation and disaster risks management and reduction in the Latin América ad Caribbean Region. Published at the Revista Terceiro Incluído ISSN 2237-079X NUPEAT-IESA-UFG, v.3, n.1, Jan./Jun., 2013, p. 37-46, Artigo 36.

- Borgo, R. L. ICT Infrastructures to support Environmental Management Monitoring and Natural Resources Control, Risks and Disaster Management. Brasília University UNB - CDS \& MCTI-CNPq Specialization Monograph. Brasília, Dicember 2007

- Borgo, R. L. Performance study of a Geostationary DVB-S2 K microwave broadband telecommunication satellite applied to a Brazil disaster management and reduction network. 2012. Electrical Enginner Máster Dissertation. Brasília University. Center of Tecnology. 